\title{
Measuring the Performance of Corporate Acquisitions: An Empirical Comparison of Alternative Metrics*
}

\author{
Richard Schoenberg \\ Senior Lecturer in Strategic Management \\ Cranfield School of Management \\ Cranfield University \\ Bedford \\ MK43 0AL
}

Tel: 01234751122

Fax: 01234750070

richard.schoenberg@cranfield.ac.uk

Published In : British Journal of Management, Vol 17, No 4, pp361-370, 2006

\section{Biographical Notes:}

Richard Schoenberg is Senior Lecturer in Strategic Management at Cranfield University School of Management. He previously held faculty positions at Cambridge University's Judge Business School and the Tanaka Business School, Imperial College London. His research focuses primarily on mergers and acquisitions, in particular organizational determinants of performance.

\footnotetext{
* The article has benefited from the constructive comments of the Editor, Gerard Hodgkinson, and two anonymous reviewers. The author would also like to thank Nardine Collier for her excellent research assistance during the revision of the paper and Noriah Abidin, Fiona Chow and Shahid Kazi for their contributions to the data collection. Earlier versions of aspects of the work were presented at the 2004 British Academy of Management Conference, St Andrews and the 2005 Academy of International Business Conference, Quebec.
} 


\section{Measuring the Performance of Corporate Acquisitions:}

\section{An Empirical Comparison of Alternative Metrics}

\section{Summary}

The choice of performance measure has long been a difficult issue facing researchers. This paper investigates the comparability of four common measures of acquisition performance: cumulative abnormal returns, managers' assessments, divestment data and expert informants' assessments. Independently each of these measures indicated a mean acquisition success rate of between $44 \%-56 \%$, within a sample of British cross-border acquisitions. However, with the exception of a positive relationship between managers' and expert informants' subjective assessments, no significant correlation was found between the performance data generated by the alternative metrics. In particular, ex-ante capital market reactions to an acquisition announcement exhibited little relation to corporate managers' ex-post assessment. This is seen to reflect the information asymmetry that can exist between investors and company management, particularly regarding implementation aspects. Overall, the results suggest that future acquisitions studies should consider employing multiple performance measures in order to gain a holistic view of outcome, while in the longer term opportunities remain to identify and refine improved metrics.

Key Words: Mergers; Acquisitions; International; Performance; Measurement 


\section{Introduction}

The choice of performance measure has long been a difficult issue facing researchers within the organisational field (Dess and Robinson, 1984; Glaister and Buckley, 1998; Kirchhoff, 1977). Finance and associated disciplines have relied on objective performance metrics such as share price movements and accounting data to assess the outcome of organisational choices. Others, for example organisational behaviour and strategic management, have frequently relied on subjective performance indicators, including managers' self reports. In some instances the use of a subjective measure has been justified by difficulties in obtaining objective data, for example because the focal unit was a constituent part of a larger organisation (Dess and Robinson, 1984).

The selection of appropriate performance metrics is of particular relevance in inter-disciplinary fields such as mergers and acquisitions, where diverse origins have led to the adoption of a broad range of performance measures within contemporary research (Larsson and Finkelstein, 1999). This is especially notable within studies that have investigated the antecedents of acquisition outcome (King, Dalton, Daily and Covin, 2004). Some have employed subjective performance assessments obtained from managers involved in the acquisition (e.g. Brock, 2005; Capron, 1999), or from external expert informants (e.g. Cannella and Hambrick, 1993; Hayward, 2002). Others have relied on objective measures including the acquirer's stockmarket returns (e.g. Carow, Heron and Saxton, 2004; Datta and Puia, 1995), or profitability gains (e.g. Hitt, Harrison, Ireland and Best, 1998). Others still have focused on whether the acquired firm is subsequently divested (e.g. Bergh, 1997; Porter, 1987).

The widespread use of alternative performance measures means prospective acquisitions researchers face a dilemma when selecting an appropriate performance variable. Indeed, authors of two recent meta-analyses, concerned with identifying the antecedents of 
acquisition outcome, caution that inconsistent use of the available performance measures may have held back knowledge development (King et al., 2004; Stahl and Voigt, 2004). Further, some of the conflicting conclusions within the acquisitions literature may be due, in part, to the adoption of different performance metrics. For example, the contradictory findings of Datta and Puia (1995) and Morosini, Shane and Singh (1998) on the impact of national culture distance on acquisition outcome arise from studies that employed different performance measures. The role of acquisition experience is another subject characterised by differing results and the use of a variety of performance metrics (e.g. Hayward, 2002; Hitt et al., 1998).

Against this background, the paper presents an empirical comparison of four alternative measures of acquisition performance. The broad proposition investigated is that there is convergence between the performance data generated by the alternative metrics. The findings contribute to our knowledge in three areas. First, they provide insights into the comparability of subjective and objective measures of acquisition performance, in particular how ex-ante capital market expectations relate to managers' perceptions of ex-post acquisition outcome. This is relevant to the interpretation of prior acquisitions studies that have employed different performance metrics. Second, the findings provide indications as to how future researchers might approach the measurement of acquisition performance. Finally, the findings add empirical data on the mixed absolute performance of cross-border acquisitions, an increasingly important form of corporate development (UNCTAD, 2000).

The origins and assumptions of each of the performance measures examined are summarised in Table 1, together with their strengths and weaknesses, and examples of studies that have employed the measure.

\section{INSERT TABLE 1 ABOUT HERE}




\section{Methodology}

The study's sample comprised 61 British acquisitions of continental European firms made between 1988 and 1990, identified from Acquisitions Monthly magazine. Inclusion in the sample was dependent upon meeting four criteria: the purchase was of a controlling interest (>50\%), the bid value was at least $£ 5 \mathrm{~m}^{1}$, performance data were attainable using at least three of the metrics listed below, and the acquisition was classified as horizontal as defined by twodigit SIC codes ${ }^{2}$.

For each acquisition in the sample, separate performance data were gathered via the following four methodologies:

Cumulative Abnormal Returns (CAR) were calculated from the acquiring firm's daily share price movements around the announcement date of the acquisition (day 0, identified from Acquisitions Monthly). Standard event study methodology using the market and risk adjusted model was employed, where the abnormal return is computed as:

$$
\text { ARit }=\text { Rit }-(\text { ai }+ \text { bi Rmt })
$$

Where,

$\mathrm{ARit}=$ the abnormal share price return of acquiring firm $\mathrm{i}$ on day $\mathrm{t}$

Rit $=$ observed share price return of acquiring firm $\mathrm{i}$ on day $\mathrm{t}$

$\mathrm{ai}=$ market model constant for acquiring firm $\mathrm{i}$

bi = beta of acquiring firm $\mathrm{i}$

\footnotetext{
${ }^{1}$ Very small acquisitions were excluded consistent with recent acquisitions studies in the finance literature employing abnormal returns methodology (e.g. Sudarsanam and Mahate, 2006). The final sample ranged in bid value from $£ 5 \mathrm{~m}$ to $£ 530 \mathrm{~m}$, with a mean of $£ 58 \mathrm{~m}$.

${ }^{2}$ Horizontal acquisitions provided a reasonably homogeneous environment in which to compare the performance measures. The focus on horizontal acquisitions is consistent with much of the recent strategic management research on acquisitions (e.g. Brock, 2005; Capron, 1999; Capron and Pieste, 2002; Ellis and Lamont, 2004; Schoenberg, 2004).
} 
$\mathrm{Rmt}=$ share price return on the market portfolio on day $\mathrm{t}$

Coefficients $\mathrm{a}$ and $\mathrm{b}$ were estimated over a three month period (-120 to -30 days), and were taken to calculate the expected returns for each security given movements in the market portfolio, here the FTSE All-Share Index. Abnormal returns due to the acquisition announcement were determined by subtracting the actual share returns from the expected returns. These were calculated over a 21 day period spanning the bid announcement (day -10 to +10) to provide the CAR for each acquisition. Use of a 21 day event period follows previous acquisitions research (e.g. Datta and Puia, 1995; Markides and Ittner, 1994), and provides an event period sufficiently long to capture market reaction, yet short enough to avoid the influence of information unrelated to the announcement ${ }^{3}$.

Managers' Subjective Assessments were gathered by postal questionnaire 3 to 5 years following acquisition completion. The respondents were current executive directors of the acquiring firm, who had also been serving as directors at the time of the acquisition. The questionnaire instrument was adapted from Datta (1991) and comprised nine performance criteria $^{4}$. Respondents were asked to indicate, using five point Likert scales, the importance assigned to each performance criterion at the time of acquisition, and the acquisition's performance relative to their expectations. A 'weighted performance' for each criterion was established by multiplying the performance score by the importance attributed to the criterion. The scale exhibited high reliability (Cronbach's Alpha=0.86) and principal components analysis

\footnotetext{
${ }^{3}$ Abnormal returns using a two day event period $(-1,0)$ were also calculated for each acquisition. The use of this data in the comparative analysis yielded qualitatively similar results to those obtained with the $(-10,+10)$ CARs.

${ }^{4}$ The criteria were: return on investment, return on sales, asset utilisation, earnings per share; share price; cash flow; tax efficiency; growth in sales revenues; purchase of undervalued assets.
} 
confirmed its uni-dimensionality. A single mean "managers' assessment" performance score was therefore computed for each acquisition ${ }^{5}$.

Questionnaire responses from more than one acquiring firm director were available for 24 of the acquisitions. Cognisant of the limitations of relying on the response of a single manager (Bowman and Ambrosini, 1997), inter-rater reliabilities were calculated using Kendall's Coefficient of Concordance for the 24 multiple respondent acquisitions (following Hayward, 2002), revealing a mean Concordance Coefficient of 0.73 between respondents. The high interrater reliabilities provide reassurance that the questionnaire responses captured a valid organisational view of acquisition performance, rather than that of one individual.

A potential limitation of this methodology is its reliance on managers' retrospective recall of the original acquisition criteria (Miller, Cardinal and Glick, 1997). The maximum five year recall period adopted here is not considered excessive. First, the respondents were directors, who are credited with high intellectual capabilities and thus a strong ability to recall events (Huber and Power, 1985). Second, acquisitions are major organisational events, which tend to be recalled more accurately and completely (Huber and Power, 1985). These two points, combined with the high levels of inter-rater reliabilities, provide confidence towards the retrospective data in the present case.

Expert Informants' Subjective Assessments were based on financial press commentary that appeared between two and four years post-acquisition, following methodology established by Datta and Grant (1990). Financial press reports on each acquisition were retrieved using the

\footnotetext{
${ }^{5}$ In a separate question, respondents also provided their "overall" rating of the acquisition's performance. The "managers' assessment" score, computed from the nine item scale, exhibited very high consistency with their "overall" performance rating $(r=0.92 ; \mathrm{p}<0.001)$.
} 
"FACTIVA" database. The performance of the acquisition implied by the press commentary was rated on a scale of 1 (very poor) to 5 (very good) by two independent Professors of Strategic Management. The Professors level of agreement was high $(\mathrm{r}=0.82 ; \mathrm{p}<0.001)$, and their aggregate rating was used in subsequent analysis.

Divestment Data captured the ownership of the acquired company at 13 years post-acquisition, consistent with the timeframes employed in prior research (Kaplan and Weisbach, 1992; Montgomery and Wilson, 1986; Porter, 1987). It was also measured at six and nine years to gain insight into divestment patterns and provide greater comparability with the timeframes of the other ex-post performance metrics examined in this study. For each of the years, the acquisition was coded 0 if it was still retained by the acquiring company, coded 1 if it was divested $^{6}$. Ownership of the acquired firm was tracked using databases including "FAME", "FACTIVA", and "Who Owns Whom". Where no, or conflicting, information was available, the acquiring company was contacted to ascertain ownership of the acquired firm, and, if divested, the year of divestiture.

\section{Results and Discussion}

\section{Performance of the Acquisitions}

Table 2 summarises the performance of the acquisitions using each of the four alternative metrics.

INSERT TABLE 2 ABOUT HERE

\footnotetext{
6 Defined as the divestiture of all assets and product lines of the acquired entity (Kaplan and Weisback, 1992).
} 
The mean CAR for the 21 day period around the acquisitions' announcement was $-0.02 \%$ (s.d.= $6.43 \%)$, and not statistically different from zero $(\mathrm{t}=-0.02)$. The acquisition announcement produced positive abnormal returns for the acquirer in $50 \%$ of cases, and negative returns in $50 \%$. These results are in line with larger studies of UK acquisitions employing short-run abnormal returns methodology (Sudarsanam and Mahate, 2006).

Managers' subjective assessments reveal that $44 \%$ are dissatisfied or highly dissatisfied with their acquisitions financial performance relative to their expectations. This echoes Rostand's (1994) findings where $45 \%$ of acquiring managers stated that their European cross-border acquisitions had not met their strategic objectives.

Expert informants' assessments classified $44 \%$ of the acquisitions as poor or very poor performers.

Finally, $11 \%$ of acquisitions in the sample were subsequently divested within six years, rising to $30 \%$ after nine years, and $56 \%$ after 13 years $^{7}$. Examination of the complete dataset showed that the average time period to divestment was nine years following completion, similar to that reported by Montgomery and Wilson (1986). The divestment rate of 56\% after 13 years is comparable to that identified in US related acquisitions (Porter, 1987).

In summary, the absolute performance of acquisitions in this sample is similar to that reported by prior studies. Interestingly, irrespective of which performance metric is employed, the overall success rate was in the region of the widely cited 50\% (Brouthers et al., 1998). The

\footnotetext{
${ }^{7} 31 \%$ of the acquiring companies were themselves acquired by year 13. In just over one third of these cases the original acquisition was divested by the new owner. These divestments are included in the overall $56 \%$.
} 
paper now turns to the comparability between the performance measures, is it the same $50 \%$ that are categorised as successful in all cases?

\section{Comparability of the Performance Measures}

Statistical comparison of the four sets of performance data were undertaken using Spearman rank-order correlations, following Glaister and Buckley $(1998)^{8}$. The results are summarised in Table 3.

\section{INSERT TABLE 3 ABOUT HERE}

High levels of agreement were found between managers' subjective performance assessments and those of expert informants. This is perhaps unsurprising given that financial journalists frequently gather their information through briefings given by the acquiring managers.

The divestment data exhibited no statistically significant association with either managers' subjective assessments or expert informants' views, regardless of the time period. The arguments of those who view divestment as a measure of acquisition performance would lead us to expect a strong association between managers' assessment of performance and their subsequent decision to retain or divest the business (Porter, 1987). The observed weak correlations suggest this association does not hold in practice. Indeed, inspection of the data relating to divestments within the first six years, i.e. broadly coincident to the time period in which the managers' assessments were collected, revealed that $29 \%$ of these divestments related to acquisitions that were viewed as very successful by the managers themselves $(>=4.0$ on the Likert scale). Overall, these results support the view that rather than failure, divestment in some

\footnotetext{
8 Pearson correlations and Chi-Square statistics were also computed and produced findings consistent with the Spearman-based results.
} 
instances signals successful restructure and profitable sale (Kaplan and Weisbach, 1992), or appropriate resource reconfiguration in response to environmental change (Capron et al., 2001).

Finally, the capital market's initial assessment of an acquisition, based on CAR methodology, exhibited no statistically significant relationship with either the objective divestment data or the two subjective performance measures. This finding is seen to reflect the contrast between the ex-ante nature of the CAR measure and the importance of the post-acquisition integration period, captured by the three ex-post performance measures investigated here.

The CAR metric is based on investors' forecasts of the future cash flow consequences of an acquisition announcement. The lack of correlation between this measure and those performance data collected ex-post supports Larsson and Finkelstein's (1999) proposition that investors may have difficulty in accurately judging the internal implementation issues that can accompany an acquisition. The integration phase of an acquisition is central to its outcome (Ellis and Lamont, 2004), but even acquiring managers have difficulty predicting all the issues that will arise (Very and Schweiger, 2001). For example, longitudinal research has revealed that issues of cultural compatibility are frequently formalised and rise in intensity only as the implementation progresses (Kavanagh and Ashkanasy, 2006). Remote external investors therefore face considerable difficulty in forecasting internal organisational matters that might arise post-acquisition. This lack of insight into the implementation phase may lead investors to consistently make erroneous estimates of the future cash flow implications of an acquisition announcement ${ }^{9}$.

\footnotetext{
${ }^{9}$ These arguments assume capital market efficiency; that all information publicly available to investors is accurately reflected in the share price. Evidence for market efficiency is available in the finance literature, as reviewed by Cuthbertson and Nitzsche (2004).
} 


\section{Conclusion}

This study has investigated the comparability of four measures of acquisition performance. Individually each measure confirmed an average success rate for cross-border acquisitions of approximately $50 \%$. However, with the exception of a positive relationship between managers' and expert informants' subjective assessments, there was no comparability between the performance data generated by the alternative metrics. These results highlight the dangers inherent in comparing studies that have employed different performance measures. This may help to explain some of the conflicting conclusions reported in the literature examining the antecedents of acquisition performance.

Looking forward, the lack of comparability suggests that future empirical work should consider employing multiple measures of acquisition performance. Acquisitions impact a range of stakeholders in differential ways. For example, capital market investors are frequently concerned with the immediate wealth effects of an acquisition announcement (King et al., 2004), the bidding firm with the acquisition's long-term outcome (Hitt et al., 1998), and employees with anticipated job losses and acculturative stress (Cartwright and Cooper, 1990). Adopting multiple performance measures would facilitate a more holistic view of acquisition outcome that takes account of a range of stakeholders. These comments are especially relevant to studies that investigate the antecedents of acquisition outcome, where the current lack of consistency of performance metrics is notable (King et al., 2004; Stahl and Voigt, 2004). It may be insightful for such studies to employ both ex-ante and ex-post assessments, to capture the initial capital market reaction and the longer-term outcome for the acquiring firm taking into account the integration experience. 
Regarding ex-ante measures, announcement CARs, by definition, capture the immediate shareholder wealth effects and investors' expectations. However, the results reported here suggest that where the longer-term outcome of the acquisition is also of interest CARs need to be complemented with an appropriate ex-post performance measure. This is especially the case where the research focus is on organisational or implementation factors, due to the information asymmetries discussed above. Future methodological studies could investigate expert informants as an alternative source of ex-ante assessments, for example experienced industry sector analysts who hold insights into both financial and operational implications.

In terms of ex-post outcome, the results confirm that divestment is unlikely to be a valid performance indicator. Managers' subjective assessments may provide a suitable ex-post measure, particularly where multiple respondents are utilised for each case to improve reliability and establish an organisational perspective. Steps should also be taken to ensure that respondents are familiar with the complete history of the acquisition. If these conditions are met, managers' assessments hold the advantage of providing a direct measure of outcome as perceived by the acquiring firm (Brouthers et al., 1998). Expert informants' provide an alternative subjective metric, and the correlation with managers' data points to their utility when the latter cannot be obtained (e.g. due to executive departure). Again, multiple informants should be employed to raise reliability.

The timescale of ex-post measurement is a further consideration. Sufficient time must be allowed for post-acquisition integration, while, for subjective measures, avoiding memory decay in recalling the original acquisition objectives. A review of the 9 studies cited in Table 1 as employing subjective ex-post measures, revealed average elapsed times prior to data collection of 3 years minimum to 5 years maximum following acquisition completion. This provides a 
useful benchmark given its consistency with managers' own 2-3 year timescale for performance delivery (Norburn and Schoenberg, 1994) and recommendations on the use of retrospective reports (Huber and Power, 1985).

More fundamentally, the results suggest opportunities remain to identify and refine improved measures of acquisition performance. This includes ex-ante measures (e.g. based on expert informants), but applies particularly to objective ex-post indicators. For example, some have argued that the realisation of acquisition synergies are best reflected in long-term accounting measures (Ravenscraft and Scherer, 1989; Hitt et al., 1998). Although no accounting metric was included in this comparison, due to the cross-border sample and concerns with the comparability of accounting data (Meeks and Meeks, 1981; Walton, 1992), future methodological studies could usefully include accounting based measures, specifically those which overcome the established difficulties in disaggregating the performance of an individual acquisition from consolidated accounts (Montgomery and Wilson, 1986; Larsson and Finkelstein, 1999). Similarly, novel measures of synergy realisation may provide avenues for future research, for example direct quantification of post-acquisition resource redeployment. Future studies might also include more diverse samples than the horizontal cross-border acquisitions employed here, to examine whether the comparability of metrics is influenced by acquisition characteristics.

While this study has focused on the measurement of acquisition performance, the need to employ and refine valid and reliable measures, and develop consistency within interdisciplinary areas, has relevance to many organisational fields (e.g. Jones and Dimitriatos, 2004). As such this study has provided a cautionary note regarding the comparability of different performance metrics and hopes to encourage further work on the 
topic. 


\section{References}

Bergh, D. (1997). 'Predicting Divestiture of Unrelated Acquisitions: An Integrative Model of Ex Ante Conditions', Strategic Management Journal, 18, pp. 715-731.

Bowman, C. and V. Ambrosini (1997). 'Using Single Respondents in Strategy Research', British Journal of Management, 8, pp. 119-131.

Brock, D. (2005). 'Multinational Acquisition Integration: The Role of National Culture in Creating Synergies', International Business Review, 14, pp. 269-288.

Brouthers, K., P. van Hastenburg, and J. van den Ven (1998). 'If Most Mergers Fail Why Are They so Popular?' Long Range Planning, 31, pp. 347-353.

Cannella, A. and D. Hambrick. (1993). 'Effects of Executive Departures on the Performance of Acquired Firms', Strategic Management Journal, 14 (S),pp. 137-152.

Capron, L. (1999). 'The Long Term Performance of Horizontal Acquisitions', Strategic Management Journal, 20, pp. 987-1018.

Capron, L., W. Mitchell, and A. Swaminathan (2001). Asset Divestiture Following Horizontal Acquisitions: A Dynamic View', Strategic Management Journal, 22, pp. 817844.

Capron, L. and N. Pistre (2002). 'When Do Acquirers Earn Abnormal Returns?', Strategic Management Journal, 23, pp. 781-794.

Carow, K., R. Heron and T. Saxton (2004). 'Do Early Birds Get the Returns? An Empirical Investigation of Early-Mover Advantages in Acquisitions', Strategic Management Journal, 25, pp563-585.

Cartwright, S. and C. Cooper (1990). 'The Impact of Mergers and Acquisitions on People at Work: Existing Research and Issues', British Journal of Management, 1, pp. 65-76.

Cuthbertson, K. and D. Nitzsche (2004). Quantitative Financial Economics $2^{\text {nd }}$ Ed. J. Wiley \& Sons, Chichester.

Datta, D. (1991). 'Organizational fit and Acquisition Performance: Effects of PostAcquisition Integration’, Strategic Management Journal, 12, pp. 281-297.

Datta, D. and J. Grant (1990). 'Relationships Between Type of Acquisition, The Autonomy Given to the Acquired Firm, and Acquisition Success: An Empirical Analysis', Journal of Management, 16, pp. 29-44.

Datta, D. and G. Puia (1995). 'Cross-Border Acquisitions: An Examination of the Influence of Relatedness and Cultural Fit on Shareholder Value Creation in US Acquiring Firms', Management International Review, 35, pp. 337-359. 
Dess, G. and R. Robinson (1984). 'Measuring Organizational Performance in the Absence of Objective Measures: The Case of the Privately-held Firm and Conglomerate Business Unit', Strategic Management Journal, 5, pp. 265-273

Ellis, K. and B. Lamont (2004). "Ideal" Acquisition Integration Approaches in Related Acquisitions of Equals: A Test of Long-Held Beliefs', Advances in Mergers and Acquisitions, 3, pp. 81-102.

Fama, E., L. Fisher, M. Jensen and R. Roll. (1969). 'The Adjustment of Stock Prices to New Information', International Economic Review, 10, pp.1-21

Glaister, K. and P. Buckley (1998). 'Measures of Performance in UK International Alliances', Organization Studies, 19, pp. 89-118.

Gregory, A. (1997). 'An Examination of the Long Run Performance of UK Acquiring Firms', Journal of Business Finance \& Accounting, 24, pp. 971-1002.

Hayward, M. (2002). 'When Do Firms Learn From Their Acquisition Experience? Evidence from 1990-1995', Strategic Management Journal, 23, pp. 21-39.

Hitt, M., J. Harrison, D. Ireland and A. Best (1998). 'Attributes of Successful and Unsuccessful Acquisitions of US Firms', British Journal of Management, 9, pp. 91-114.

Huber, G. and D. Power (1985). 'Retrospective Reports of Strategic-Level Managers: Guidelines for Increasing their Accuracy', Strategic Management Journal, 6, pp171-180.

Jones, M. and P. Dimitriatos (2004). Emerging Paradigms in International Entrepreneurship. Edward Elgar, Cheltenham.

Kaplan, S. and M. Weisbach (1992). 'The Success of Acquisitions: Evidence from Divestitures', Journal of Finance. 47, pp. 107-138.

Kavanagh, M and N. Ashkanasy (2006) 'The Impact of Leadership and Change Management Strategy on Organizational Culture and Individual Acceptance of Change During a Merger', British Journal of Management, 17 (forthcoming)

King, D., D. Dalton, C. Daily and J. Covin (2004). 'Meta-Analyses of Post-Acquisition Performance: Indications of Unidentified Moderators', Strategic Management Journal, 25, pp. 187-200.

Kirchhoff, B. (1977). 'Organization Effectiveness Measurement and Policy Research', Academy of Management Review, 2, pp. 347-355

Krug, J. and W. Hegarty (2001). 'Predicting who Stays and Leaves After an Acquisition: A Study of Top Managers in Multinational Firms', Strategic Management Journal, 22, pp. 185196 
Larsson, R. and S. Finkelstein (1999). 'Integrating Strategic, Organizational, and Human Resource Perspectives on Mergers and Acquisitions: A Case Survey of Synergy Realization', Organization Science, 10, pp. 1-26.

Lubatkin, M. and R. Shrieves (1986). 'Towards Reconciliation of Market Performance Measures to Strategic Management Research', Academy of Management Review, 11, pp. 497512.

Mahoney, T. (1967). 'Managerial Perceptions of Organizational Effectiveness', Management Science, 14, pp. B76-B91

Markides, C. and C. Ittner (1994). 'Shareholder Benefits from Corporate International Diversification: Evidence from US International Acquisitions', Journal of International Business Studies, 25, pp. 343-365.

Meeks, G. and J. Meeks (1981). 'Profitability Measures as Indicators of Post-Merger Efficiency', Journal of Industrial Economics, 29, pp. 335-344.

Miller, C., L. Cardinal and W.Glick (1997) "Retrospective Reports in Organisational Research: A Reexamination of Recent Evidence", Academy of Management Journal, 40, pp189-204

Montgomery, C. and V. Wilson (1986). 'Mergers that Last: A Predictable Pattern?', Strategic Management Journal, 7, pp. 91-96.

Morosini, P., S. Shane and H. Singh (1998). 'National Cultural Distance and Cross-Border Acquisition Performance', Journal of International Business Studies, 29, pp. 137-158.

Norburn, D. and R. Schoenberg (1994). 'European Cross-Border Acquisition: How Was It for You?', Long Range Planning, 27, pp25-34.

Porter, M. (1987). 'From Competitive Advantage to Corporate Strategy'. Harvard Business Review, 65(3), pp. 43-59.

Ravenscraft, D. and F. Scherer. (1987). Mergers, sell-offs, and economic efficiency. Brookings Institution, Washington.

Ravenscraft, D. and F. Scherer. (1989). 'The Profitability of Mergers', International Journal of Industrial Organisation, 7, pp101-116.

Rostand, A. (1994). 'Optimizing Managerial Decisions during the Acquisition Integration Process'. Paper presented to 14th Annual Strategic Management Society International Conference, Paris, France.

Schoenberg, R. (2004). 'Dimensions of Management Style Compatibility and Cross-Border Acquisition Outcome'. Advances in Mergers and Acquisitions, 3, pp. 149-175.

Stahl, G. and A. Voigt (2004). 'Meta-Analyses of the Performance Implications of Cultural Differences in Mergers and Acquisitions: Integrating Strategic, Financial and Organizational 
Perspectives'. Academy of Management Best Conference Paper Proceedings, New Orleans, ppI1-I6.

Sudarsanam, S. and A. Mahate (2006). 'Are friendly acquisitions too bad for shareholders and managers? Long term value creation and top management turnover in hostile and friendly acquirers', British Journal of Management, 17 (forthcoming)

UNCTAD (2000). 'World Investment Report 2000: Cross-Border Mergers and Acquisitions and Development'. UNCTAD, Geneva.

Very, P., M. Lubatkin, R. Calori and J. Veiga (1997). 'Relative Standing and the Performance of Recently Acquired European Firms', Strategic Management Journal, 18, pp. 593-614.

Very, P. and D. Schweiger (2001). 'The Acquisition Process as a Learning Process: Evidence from a Study of Critical Problems and Solutions in Domestic and Cross-Border Deals', Journal of World Business, 36, pp. 11-32.

Walton, P. (1992). 'Differential reporting and the European community: a suitable case for treatment', European Business Journal, 4, pp. 43-50. 
Table 1: Qualitative Comparison of Four Measures of Acquisition Performance

\begin{tabular}{|c|c|c|c|c|}
\hline Measure & $\begin{array}{l}\text { Underlying rationale/assumptions of the } \\
\text { measure }\end{array}$ & Strengths of the measure & Weaknesses of the measure & \begin{tabular}{|l|} 
Examples of studies \\
using the measure \\
\end{tabular} \\
\hline $\begin{array}{l}\text { Cumulative } \\
\text { abnormal } \\
\text { returns }\end{array}$ & $\begin{array}{l}\text { Origins in the financial economics literature, } \\
\text { assesses the impact of an event (acquisition } \\
\text { announcement) on a firm's share price by } \\
\text { estimating the "normal" or expected return to } \\
\text { its share in the absence of an event and } \\
\text { comparing it to the actual return achieved } \\
\text { during a period of time around the event } \\
\text { (Fama et al., 1969). } \\
\text { Strategic management studies generally utilise } \\
\text { event windows around the acquisition } \\
\text { announcement (e.g. - } 10,+10 \text { days), providing } \\
\text { ex-ante performance forecasts from the } \\
\text { perspective of acquiring firm shareholders. } \\
\text { Finance studies have also employed long run } \\
\text { event windows (e.g. } 0,+36 \text { months. See } \\
\text { Sudarsanam and Mahate (2006; appendix) for } \\
\text { a useful discussion on long run abnormal } \\
\text { returns methodology). } \\
\text { Assumes capital market efficiency, such that } \\
\text { share price movements in response to the } \\
\text { event accurately reflect investors' assessment } \\
\text { of the future cash flow implications of the } \\
\text { transaction. }\end{array}$ & $\begin{array}{l}\text { Capital market provides a fully } \\
\text { objective assessment (Lubatkin and } \\
\text { Shrieves, 1986). } \\
\text { No possibility of bias from firm } \\
\text { executives, and share prices "see } \\
\text { through" accounting manipulation } \\
\text { (Lubatkin and Shrieves, 1986). } \\
\text { Share price movements represent the } \\
\text { only direct measure of shareholder } \\
\text { value (Lubatkin and Shrieves, 1986). }\end{array}$ & $\begin{array}{l}\text { Limited to cases where the acquiring } \\
\text { firm is publicly quoted. } \\
\text { Does not measure realised operating } \\
\text { performance, but investors' forecast } \\
\text { of the future cash flow implications } \\
\text { of the acquisition (Montgomery and } \\
\text { Wilson, 1986). } \\
\text { Share price movements may reflect } \\
\text { other actions of the firm extraneous } \\
\text { to the event. Particularly an issue for } \\
\text { long run CARs, whose use is } \\
\text { generally limited to large acquisitions } \\
\text { (Lubatkin and Shrieves, 1986). } \\
\text { Results obtained may be subject to } \\
\text { technical aspects of the } \\
\text { computational procedure, including } \\
\text { choice of daily vs monthly share data } \\
\text { (Lukatkin and Shrieves, 1986), the } \\
\text { relevance of the benchmark market } \\
\text { index (Gregory, 1997), and the } \\
\text { appropriateness of the event period } \\
\text { (Lubatkin and Shrieves, 1986). }\end{array}$ & $\begin{array}{l}\text { Capron and Pistre, } 2002 \\
\text { Carow et al., 2004 } \\
\text { Datta and Puia, } 1995 \\
\text { Gregory, } 1997 \\
\text { Hayward, } 2002 \\
\text { Markides and Ittner, } \\
1994 \\
\text { Sudarsanam and } \\
\text { Mahate, } 2006\end{array}$ \\
\hline $\begin{array}{l}\text { Managers' } \\
\text { subjective } \\
\text { assessments }\end{array}$ & $\begin{array}{l}\text { Origins in the management literature as an } \\
\text { operationalisation of a multidimensional } \\
\text { performance construct (Mahoney, 1967). } \\
\text { Executives are asked to rate the extent to } \\
\text { which their original objectives (for the } \\
\text { acquisition) have been met along a number of } \\
\text { specified dimensions. } \\
\text { A separate single question asking executives } \\
\text { to rate their satisfaction with the "overall" }\end{array}$ & $\begin{array}{l}\text { Allows a composite view of } \\
\text { performance that takes into account } \\
\text { differing management objectives } \\
\text { (Brouthers et al., 1998). } \\
\text { Applicable across all types of } \\
\text { acquisitions. } \\
\text { Managers' perceptions define their } \\
\text { reality and influence their behaviour }\end{array}$ & $\begin{array}{l}\text { May be subject to managerial bias } \\
\text { (Lubatkin and Shrieves, 1986). } \\
\text { Assessment may be idiosyncratic to } \\
\text { the individual manager providing the } \\
\text { information (Bowman and } \\
\text { Ambrosini, 1997). } \\
\text { Dependant upon accurate } \\
\text { retrospective recall of respondents }\end{array}$ & \begin{tabular}{|l} 
Brock, 2005 \\
Brouthers et al., 1998 \\
Capron, 1999 \\
Datta, 1991 \\
Datta and Grant, 1990 \\
Schoenberg, 2004 \\
Very et al., 1997
\end{tabular} \\
\hline
\end{tabular}




\begin{tabular}{|c|c|c|c|c|}
\hline & $\begin{array}{l}\text { performance is also frequently employed to } \\
\text { establish convergent validity (Dess and } \\
\text { Robinson, 1984). } \\
\text { Most commonly used to capture the } \\
\text { perspective of acquiring firm management } \\
\text { (Brouthers et al., 1998); some studies have } \\
\text { employed views of acquired firm executives } \\
\text { (Brock, 2005; Very et al., 1997). } \\
\text { Data usually gathered 3-5 years after event, } \\
\text { providing ex-post assessment. }\end{array}$ & $\begin{array}{l}\text { and attitudes (Krug and Hegarty, } \\
\text { 2001). } \\
\text { Can be utilised where objective } \\
\text { measures are not available (Dess and } \\
\text { Robinson, 1984). }\end{array}$ & $\begin{array}{l}\text { (Miller et al., 1997). } \\
\text { Results may be subject to } \\
\text { respondents' familiarity with the } \\
\text { original objectives of acquisition } \\
\text { (Datta, 1991). }\end{array}$ & \\
\hline $\begin{array}{l}\text { Expert } \\
\text { informants' } \\
\text { subjective } \\
\text { assessments }\end{array}$ & $\begin{array}{l}\text { A variant of the above, this seeks the views of } \\
\text { expert informants as to the acquisition's } \\
\text { performance, typically using direct data from } \\
\text { stock market analysts (Haywood, 2002), or } \\
\text { indirectly via the rating of financial press } \\
\text { reports and commentary (Datta and Grant, } \\
\text { 1990; Datta, 1991). }\end{array}$ & $\begin{array}{l}\text { Provides external assessment that is } \\
\text { "independent" of both management } \\
\text { and capital providers. } \\
\text { Can be utilised where both managers' } \\
\text { own assessments and objective } \\
\text { performance measures are } \\
\text { unavailable (Cannella and Hambrick, } \\
\text { 1993). }\end{array}$ & $\begin{array}{l}\text { May reflect the expert informant's } \\
\text { subjective bias and may be } \\
\text { impressionistic (Cannella and } \\
\text { Hambrick, 1993). } \\
\text { Data may be subject to differences in } \\
\text { the experts understanding of the } \\
\text { definitions or bases on which they are } \\
\text { making performance judgements } \\
\text { (Cannella and Hambrick, 1993). }\end{array}$ & $\begin{array}{l}\text { Cannella and Hambrick, } \\
1993 \\
\text { Datta, } 1991 \\
\text { Datta and Grant, } 1990 \\
\text { Hayward, } 2002\end{array}$ \\
\hline Divestment & $\begin{array}{l}\text { Origins in the industrial organisation and } \\
\text { business policy literature, this measure } \\
\text { identifies whether an acquired firm has } \\
\text { subsequently been divested, with divestment } \\
\text { deemed to show managements' dissatisfaction } \\
\text { with the acquisition's performance } \\
\text { (Montgomery and Wilson, 1986; Ravenscraft } \\
\text { and Scherer, 1987). } \\
\text { "The underlying assumption is that a company } \\
\text { will generally not divest or close down a } \\
\text { successful business except in a comparatively } \\
\text { few special cases" (Porter, 1987: 47). }\end{array}$ & $\begin{array}{l}\text { "A relatively simple way to gauge } \\
\text { success" (Porter, 1987: 47), that does } \\
\text { not require detailed financial } \\
\text { information. }\end{array}$ & $\begin{array}{l}\text { Coarse-grained measure. Divestment } \\
\text { may indicate strategic failure (Porter, } \\
\text { 1987), but equally may indicate } \\
\text { profit taking following successful } \\
\text { restructure (Kaplan and Weisbach, } \\
\text { 1992), or appropriate resource } \\
\text { reconfiguration in response to } \\
\text { environmental change (Capron et al., } \\
\text { 2001). }\end{array}$ & $\begin{array}{l}\text { Bergh, } 1997 \\
\text { Montgomery and } \\
\text { Wilson, } 1986 \\
\text { Porter, } 1987 \\
\text { Ravenscraft and } \\
\text { Scherer, } 1987\end{array}$ \\
\hline
\end{tabular}


Table 2: Acquisition Performance from Alternative Measures

\begin{tabular}{|c|c|c|c|c|}
\hline Measure & Mean & $\begin{array}{l}\text { Standard } \\
\text { Deviation }\end{array}$ & \% Successful & \% Unsuccessful \\
\hline $\begin{array}{c}\text { Announcement } \\
\text { CARs }^{\mathrm{a}}\end{array}$ & $-0.02 \%$ & $6.43 \%$ & $\begin{array}{c}50 \% \\
(+\mathrm{ve} \text { CAR) }\end{array}$ & $\begin{array}{c}50 \% \\
\text { (-ve CAR) }\end{array}$ \\
\hline $\begin{array}{c}\text { Managers' } \\
\text { Assessment }\end{array}$ & 2.99 & 1.03 & $\begin{array}{c}56 \% \\
\text { (Neut to Hi Satis) }\end{array}$ & $\begin{array}{c}44 \% \\
\text { (Hi Disatis to Disatis) }\end{array}$ \\
\hline $\begin{array}{c}\text { Expert } \\
\text { Informants' }^{\prime} \\
\text { Assessment }^{\mathrm{c}}\end{array}$ & 2.74 & 1.01 & $\begin{array}{c}56 \% \\
\text { (Neut to V.Good) }\end{array}$ & $\begin{array}{c}44 \% \\
\text { (V.Poor to Poor) }\end{array}$ \\
\hline $\begin{array}{c}\text { Subsequent } \\
\text { Divestment }^{\mathrm{d}} \text { : } \\
13 \text { years } \\
9 \text { years } \\
6 \text { years }\end{array}$ & (0/1 variable) & (0/1 variable) & $\begin{array}{l}44 \% \\
70 \% \\
89 \%\end{array}$ & $\begin{array}{l}56 \% \\
30 \% \\
11 \%\end{array}$ \\
\hline
\end{tabular}

a. Acquisitions characterised as successful where CAR was positive, unsuccessful where CAR was negative.

b. Data represent weighted mean scores on scale of 1.0 to 5.0, calculated from questionnaire responses.

Acquisitions characterised as successful where weighted mean score $>=3.0$, unsuccessful where score $<3.0$.

c. Independent assessment of press commentary on scale of 1.0 to 5.0. Acquisitions characterised as successful where mean score $>=3.0$, unsuccessful where score $<3.0$.

d. Divestment of the acquired firm by year $n$ was taken to signify an unsuccessful acquisition (coded 1), retention a successful acquisition (coded 0$)$.

Table 3: Spearman Rank-Order Correlations Among Alternative Acquisition Performance Measures

\begin{tabular}{|l|c|c|c|}
\hline & $\begin{array}{c}\text { Announcement } \\
\text { CARs }\end{array}$ & $\begin{array}{c}\text { Managers' } \\
\text { Subjective } \\
\text { Assessment }\end{array}$ & $\begin{array}{c}\text { Expert } \\
\text { Informants' } \\
\text { Assessment }\end{array}$ \\
\hline Announcement CARs & - & - & \\
\hline $\begin{array}{l}\text { Managers' Subjective } \\
\text { Assessment }\end{array}$ & 0.15 & $0.62^{* * *}$ & - \\
\hline $\begin{array}{l}\text { Expert Informants' } \\
\text { Assessment }\end{array}$ & 0.17 & -0.19 & 0.09 \\
\hline $\begin{array}{c}\text { Divestment: 13 years } \\
\text { 9 years } \\
\text { 6 years }\end{array}$ & -0.20 & -0.13 & -0.10 \\
\end{tabular}

**** $\mathrm{p}<0.001$. 